\title{
Expression of the interleukin 6 receptor in primary renal cell carcinoma
}

Valérie Costes, Janny Liautard, Marie-Christine Picot, Maxime Robert, Nadine Lequeux, Jean Brochier, Pierre Baldet, Jean-François Rossi

\begin{abstract}
Aims-Interleukin 6 (IL-6) is expressed in the majority of renal cell carcinomas and has an important role in the proliferation of some renal cell carcinoma cell lines. This action is mediated by two membrane proteins, gp80 (the IL-6 receptor; IL-6R), which binds IL-6, and gp130, which transduces the signal. The soluble form of $\mathrm{gp} 80$ (sIL-6R) is able to activate gp130 when complexed to the IL-6 molecule. These considerations prompted an investigation of IL-6R expression in this malignancy. IL-6, C reactive protein (CRP), and sIL-6R were also measured in serum and correlated to clinical and pathological features.
\end{abstract}

Methods-Immunostaining was performed on cryostat sections from renal cell carcinoma tumours with $\mathrm{M91}$, an anti-IL-6R monoclonal antibody, using the alkaline phosphatase antialkaline phosphatase technique. The proliferation index was measured using the KI-67 monoclonal antibody. CRP, IL-6, and sIL-6R were measured in serum before nephrectomy, using an immunoenzymatic or immunoradiometric assay.

Results-There were significant differences in survival in patients with tumours larger than $8 \mathrm{~cm}$, metastasis at diagnosis, high nuclear grade tumours, detectable serum concentrations of IL-6 (correlated to CRP serum concentration), more than $4 \%$ proliferating cells, and the presence of the IL-6R in situ. Furthermore, the serum IL-6 concentration correlated with tumour size and stage. The mean serum sIL-6R concentration was not significantly different from that observed in $\mathbf{4 0}$ normal subjects. Tumour IL-6R expression was present in 10 samples. There was a significant association between the presence of the IL-6 receptor in tumours and tumour stage, nuclear grade, proliferation index, and serum IL-6.

INSERM U291, 99 rue du Puech Villa, 34000 Montpellier, France

J Liautard

J Brochier

Department of

Haematology-Oncology,

CHU Lapeyronie,

34295, Montpellier

Cedex 5, France

J-F Rossi

Correspondence to:

Dr Costes.

Accepted for publication

12 June 1997
Keywords: renal cell carcinoma; interleukin 6; IL-6 receptor; $\mathrm{C}$ reactive protein
Renal cell carcinoma arising from renal tubular epithelial cells is the third most common adult malignancy. ${ }^{1}$ Recent studies highlighted the presence of chromosomal abnormalities including allelic loss of chromosome $3 \mathrm{p}^{23}$ and possible in vitro tumour induction after v-src oncogene transfection of normal tubular cells. ${ }^{4}$ Growth factors implicated in renal cell carcinoma progression have not been defined in vivo. Interleukin 6 (IL-6) is a multifunctional cytokine that regulates haematopoiesis, the production of acute phase proteins, and the immune response; it plays a critical role in the differentiation of B cells into plasma cells. IL- 6 is produced by a variety of cells including macrophages, $\mathrm{T}$ cells, $\mathrm{B}$ cells, fibroblasts, endothelial cells, and epithelial cells, particularly renal mesangial and tubular cells. ${ }^{5}$ IL-6 pleiotropic functions are mediated by two membrane proteins, an $80 \mathrm{kDa}$ binding receptor (IL-6R) and the gp130 protein that transduces the signal. ${ }^{6}$ Soluble gp80 (sIL-6R) binds to IL-6 and the IL-6/sIL-6R complex binds and activates the gp130 transducer chain. ${ }^{78}$ In addition to its physiological functions, IL-6 exerts growth stimulatory activities in a variety of malignancies, particularly B cell neoplasias including multiple myeloma. ${ }^{9}$ In this disease, the serum IL- 6 and sIL-6R concentrations have been found to be powerful prognostic factors. ${ }^{10-12}$ Serum concentrations of IL- 6 have been detected in some patients with renal cell carcinoma and IL- 6 accounted for most of the paraneoplastic symptoms observed in these patients. ${ }^{13}{ }^{14}$ Moreover, high serum IL-6 concentrations have been correlated with poor survival. ${ }^{13}{ }^{15} \mathrm{IL}-6$ is known to induce autocrine growth in renal cell carcinoma cell lines in vitro, ${ }^{16}$ although this has not been found regularly. ${ }^{17}$ Takenawa et al analysed IL-6 and IL-6R expression in normal and tumorous renal tissues from patients after nephrectomy. IL-6 gene expression was detected in more than $50 \%$ of renal cell carcinoma cases and the presence of the IL- 6 cytoplasmic protein was confirmed by immunohistochemistry. Using the conplementary DNA polymerase chain reaction, they detected IL-6R transcripts in all specimens. ${ }^{18}$ These data provide evidence that IL-6 and its receptor may play a crucial role in proliferation of renal cell carcinoma and in the development of symptoms.

Using an anti-IL-6R monoclonal antibody and immunohistochemistry, we analysed the expression of this protein in 38 primary renal cell carcinoma patients at diagnosis; tissues were obtained after nephrectomy and 
evaluated for proliferative status by $\mathrm{KI}-67$ labelling. IL-6 and sIL-6R serum concentrations were also measured and correlated to clinical and pathological features.

\section{Materials and methods}

PATIENTS AND SAMPLES

Tissue samples of primary renal cell carcinoma were obtained surgically from 38 patients at diagnosis. Definitive staging was determined according to Robson's classification. ${ }^{19}$ Histological diagnosis was based on examination of haematoxylin and eosin stained slides from paraffin embedded tissue sections. For all patients, a tumour sample was frozen at $-20^{\circ} \mathrm{C}$ in OCT compound (Miles, Elkhart, Indiana, USA). Serum and plasma samples were obtained from all untreated patients just before surgical nephrectomy and stored at $-20^{\circ} \mathrm{C}$ until assay. Serum and plasma samples were also obtained from a control population including 40 healthy donors with comparable sex and age distributions.

DETERMINATION OF IL-6 SERUM CONCENTRATION Serum IL-6 concentrations were measured in samples from 25 patients using a commercially available enzyme immunoassay (Immunotech, Marseille, France). The test detection limit was $10 \mathrm{pg} / \mathrm{ml}$, and lower concentrations were considered to be undetectable.

DETERMINATION OF SERUM C REACTIVE PROTEIN CONCENTRATION

Serum C reactive protein (CRP) concentrations were measured using a fluorescence polarisation immunoenzymatic assay (Abbott Laboratories, Chicago, Illinois, USA). The detection limit of the CRP assay was $2.5 \mathrm{mg} / \mathrm{l}$.

DETERMINATION OF THE SIL-6R SERUM

CONCENTRATION

An immunoradiometric assay was performed with the PM-1 monoclonal antibody. Flat bottom microtitration plates with breakaway wells (Nunc, Roskilde, Denmark) were coated with PM-1 monoclonal antibody $(1 \mu \mathrm{g} / \mathrm{ml})$ in $100 \mu \mathrm{l}$ of $0.1 \mathrm{M}$ Tris- $\mathrm{HCl}(\mathrm{pH} 9)$ for 16 hours at $4^{\circ} \mathrm{C}$ and washed three times with phosphate buffered saline (PBS) Tween 20. Each well was then saturated with $200 \mu \mathrm{l} 3 \%$ bovine serum albumin (BSA) in PBS for four hours at room temperature. After three washings in PBS/ Tween $20,50 \mathrm{ml}$ of recombinant human sIL-6R or patient serum, diluted in PBS $/ 0.2 \%$ BSA, was added along with $50 \mu \mathrm{l}$ of iodinated MT18 monoclonal antibody $\left(3 \times 10^{8}\right.$ counts/ $\mathrm{min} / \mathrm{ml}$ ) in $\mathrm{PBS} / 0.2 \% \mathrm{BSA}$ in the presence of purified mouse immunoglobulins. Plates were stirred during overnight incubation at $4^{\circ} \mathrm{C}$, then washed three times with PBS/Tween 20 and the radioactivity in each well was measured in a $\gamma$ counter. A standard curve was plotted with percentages of maximal bound radioactivity as a function of recombinant human sIL-6R concentrations in the different patient sera assayed. With purified recombinant human sIL-6R, concentrations of up to $100 \mathrm{ng} / \mathrm{ml}$ could be measured accurately. Sensitivity, defined as the minimal recombinant human
sIL-6 concentration giving a signal difference with background standard deviation, was determined to be $1 \mathrm{ng} / \mathrm{ml}$. An IL- 6 concentration below $20 \mathrm{ng} / \mathrm{ml}$ did not interfere with this assay. PM-1 and MT18 anti-IL-6R monoclonal antibodies and recombinant human sIL-6R have been described previously. ${ }^{80}$

\section{IMMUNOHISTOCHEMISTRY}

Immunostaining was performed on $5 \mu \mathrm{m}$ frozen sections fixed in cold ethanol/acetone using a Techmate 500 automate (Dako A/S, Glostrup, Denmark). As previously shown, seven monoclonal antibodies produced in INSERM Unit 291 (Montpellier, France) were tested on a myeloma cell line (XG7) which is known to express IL-6R strongly. ${ }^{21}{ }^{22}$ Using flow cytometry (Facscan, Becton Dickinson, Mountain view, California, USA) and immunochemistry, the M91 monoclonal antibody constantly gave positive labelling within the $0.05-0.5 \mathrm{mg} / \mathrm{ml}$ range without false positive staining.

The MIB-1 mouse IgG monoclonal antibody (Immunotech) was used for cell proliferation analysis. It reacts with the KI-67 nuclear antigen associated with cell proliferation. This antigen is present throughout the cell cycle $\left(G_{1}\right.$, $S, G_{2}$, and $M$ phases) and absent in resting $\left(G_{0}\right)$ cells. Mouse immunoglobulins of the same isotype were used as negative controls. After rehydration in PBS, slides were incubated with the primary monoclonal antibody for 30 minutes at room temperature. Sections were washed in PBS and then incubated with diluted (1/25) rabbit antimouse immunoglobulin ( $Z$ 259; Dako) in PBS for 30 minutes at room temperature. Finally, sections were incubated with alkaline phosphatase and mouse monoclonal antialkaline phosphatase (D 651; Dako) at a 1/25 dilution. The immunohistochemical reaction was then revealed in the dark using fast red (Sigma, St Louis, Michigan, USA) as chromogenic substrate and counterstained with haematoxylin. Double staining was performed using fast red and fast blue (Sigma) chromogens in succession. Positive and negative controls were obtained for each reaction.

IL-6R cytoplasmic positive cells and KI-67 positive nuclei were counted at $\times 25$ magnification on a Leitz laborlux 25 microscope (Leica, Rueil Malmaison, France). Microscope fields in the sections were randomly chosen from left to right and up to down. In each case, the immunostained slides were evaluated by counting at least 1000 adenocarcinoma renal cells in four different fields; lymphocytes and endothelial cells were carefully avoided. Fields were accepted for evaluation if they did not contain areas of extensive necrosis, nonspecific background staining or sectioning artefacts. The results are expressed as the percentage of positive cells.

\section{STATISTICAL ANALYSIS}

Data were first assessed by examining the relation between each predictor factor. For categorical variables, $\chi^{2}$ analysis was used; Fisher's exact test was used if $\chi^{2}$ analysis was not valid. The continuous variable correlations were 


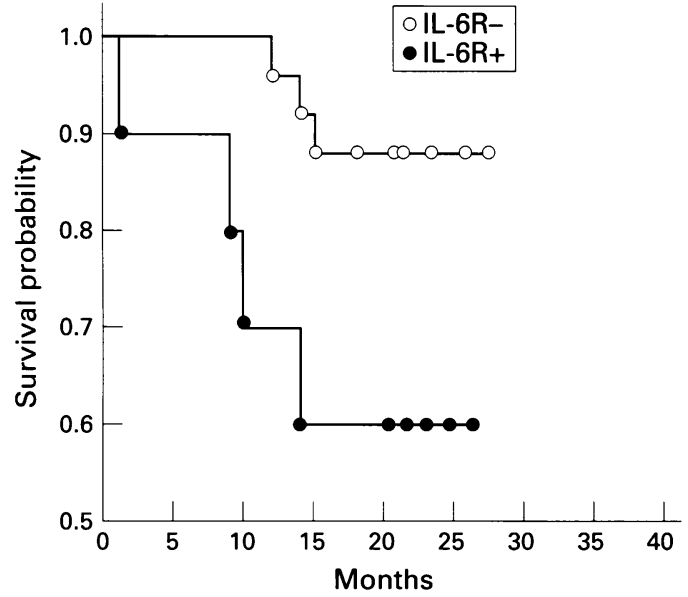

Figure 1 Overall survival distribution according to the presence of the $I L-6$ receptor.

performed using a non-parametric method (Kendall rank correlation coefficient). Two means or more were compared with the MannWhitney test and Kruskal-Wallis test, respectively. Survival time was defined as the time elapsed from the date of the surgical operation until death or until 30 April 1995 (the censoring date for the study). The Kaplan-Meier method (product limit) provides actuarial estimates of survival probability. We examined the effects on median survival of each potential factor determining survival. Differences in survival patterns between groups were evaluated using the log rank test. No multivariate analysis (Cox model) was performed because of the limited number of observations. The SAS statistical software package, version 6.08 (PROC Lifetest, PROC NPAR1WAY, PROC CORR), was used for the statistical analysis. ${ }^{23-25}$

\section{Results}

PATIENT POPULATION

Thirty eight untreated patients were included in this study, 27 men and 11 women. The mean age was 61.2 years (range $39-83$ years). Clini$\mathrm{cal}$ and pathological data are summarised in table 1 . There were seven patients with stage I tumours (18.4\%), 19 with stage II tumours

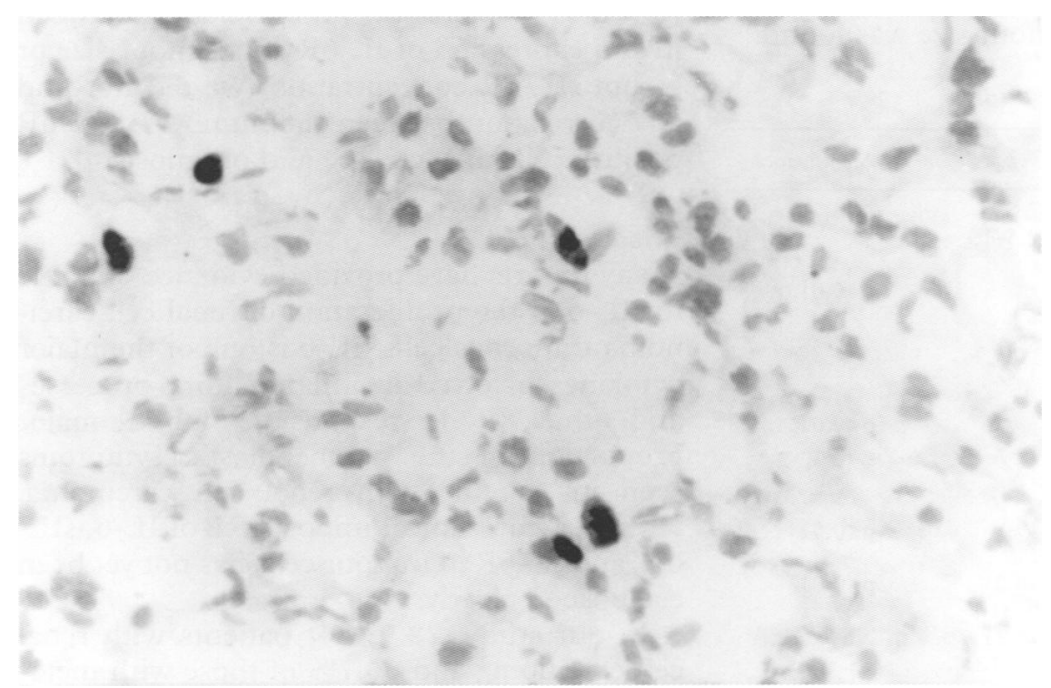

Figure 2 Nuclei positively stained with antibody KI-67 in a case of renal carcinoma. (Haematoxylin and eosin, fast red stained; original magnification $\times 250$.)
Table 1 Clinical and pathological characteristics of

\begin{tabular}{|c|c|c|c|c|c|}
\hline Patient & Sex & Age & $\begin{array}{l}\text { Tumour size } \\
(\mathrm{cm})\end{array}$ & Grade & Stage \\
\hline 1 & $\mathbf{M}$ & 72 & 7.5 & G2 & IV \\
\hline 2 & M & 67 & 4 & G1 & II \\
\hline 3 & $\mathbf{M}$ & 75 & 6 & G1 & II \\
\hline 4 & $\mathbf{M}$ & 46 & 4 & G2 & II \\
\hline 5 & M & 82 & 3.5 & G3 & IV \\
\hline 6 & $\mathbf{M}$ & 75 & 7.5 & G2 & II \\
\hline 7 & $\mathrm{~F}$ & 45 & 3 & G1 & I \\
\hline 8 & $\mathbf{M}$ & 73 & 7 & G2 & II \\
\hline 9 & $\mathrm{~F}$ & 43 & 2.2 & G1 & I \\
\hline 10 & $\mathrm{~F}$ & 48 & 13 & G3 & IV \\
\hline 11 & M & 62 & 2.8 & G2 & II \\
\hline 12 & $\mathbf{M}$ & 58 & 2.5 & G2 & II \\
\hline 13 & $M$ & 73 & 6.5 & G2 & II \\
\hline 14 & $\mathrm{~F}$ & 58 & 8 & G1 & I \\
\hline 15 & $\mathbf{M}$ & 39 & 3.5 & Gl & II \\
\hline 16 & M & 73 & 5.5 & G2 & IV \\
\hline 17 & M & 74 & 7.5 & G3 & III \\
\hline 18 & $\mathrm{~F}$ & 74 & 2.2 & G1 & I \\
\hline 19 & M & 57 & 3 & G1 & II \\
\hline 20 & $\mathbf{M}$ & 60 & 7.5 & G2 & III \\
\hline 21 & M & 59 & 12 & G2 & II \\
\hline 22 & M & 71 & 8 & G2 & I \\
\hline 23 & $\mathbf{M}$ & 63 & 12 & G1 & II \\
\hline 24 & M & 67 & 2.4 & G3 & II \\
\hline 25 & $\mathrm{~F}$ & 65 & 13 & G3 & IV \\
\hline 26 & $\mathrm{~F}$ & 83 & 7 & G3 & II \\
\hline 27 & M & 58 & 5 & G2 & III \\
\hline 28 & $\mathbf{M}$ & 56 & 5 & G1 & II \\
\hline 29 & $\mathbf{M}$ & 53 & 7 & G1 & II \\
\hline 30 & $F$ & 66 & 3 & G2 & I \\
\hline 31 & $\mathbf{M}$ & 62 & 4.5 & G2 & III \\
\hline 32 & $\mathbf{M}$ & 69 & 5.5 & G1 & III \\
\hline 33 & $\mathbf{M}$ & 56 & 8 & G1 & II \\
\hline 34 & M & 53 & 8 & G2 & III \\
\hline 35 & $\mathrm{~F}$ & 76 & 3.5 & G2 & I \\
\hline 36 & $\mathbf{M}$ & 61 & 11 & G1 & II \\
\hline 37 & $\mathrm{~F}$ & 45 & 11 & G3 & IV \\
\hline 38 & $\mathrm{~F}$ & 51 & 11 & G2 & II \\
\hline
\end{tabular}

(50\%), six with stage III tumours (15.8\%), and six with stage IV tumours $(15.8 \%)$. Nineteen patients $(50 \%)$ had high local tumour burden $(>6 \mathrm{~cm})$. Most tumours $(17 ; 44.7 \%)$ were intermediate nuclear grade, according to Furhman's system. ${ }^{26}$ The mean follow up was 14 months (range 1-28 months). The overall survival curves indicated a two year survival rate of $81 \%$ with a standard error of $6.4 \%$.

There were significant survival differences when tumours were larger than $8 \mathrm{~cm}(56 \% v$ $86 \%)$, there were metastases at diagnosis $(33 \%$ $v 90 \%$ ), high nuclear grade tumours (G3) $(57 \%$ v 86\%), detectable serum IL-6 activity $(70 \%$ v $85 \%)$, more than $4 \% \mathrm{KI}-67$ positive nuclei $(63 \% v 88 \%)$, and presence of IL-6R in situ $(60 \% v 89 \%)$ (fig 1$)$. Survival was not correlated with sex, age, or serum sIL-6R concentration.

SERUM IL-6 AND CRP CONCENTRATIONS

Eleven of the 38 patients $(28.9 \%)$ including four of six patients with metastatic disease $(66.6 \%)$ had detectable IL-6 in their serum with a mean concentration of $62 \mathrm{pg} / \mathrm{ml}$ (range 17.5-240). IL-6 was not detected (<10 pg/ml) in normal controls. CRP serum concentrations correlated significantly with serum concentrations of IL-6 ( $p=0.0001, r=0.69)$. Patients with undetectable concentrations of IL-6 in their serum had a mean CRP concentration of $2.8 \mathrm{mg} / \mathrm{l}$, while patients with detectable IL-6 concentrations had a mean CRP concentration of $54.1 \mathrm{mg} / 1$. Serum IL-6 concentrations were correlated with tumour size $(p=0.0087$, 


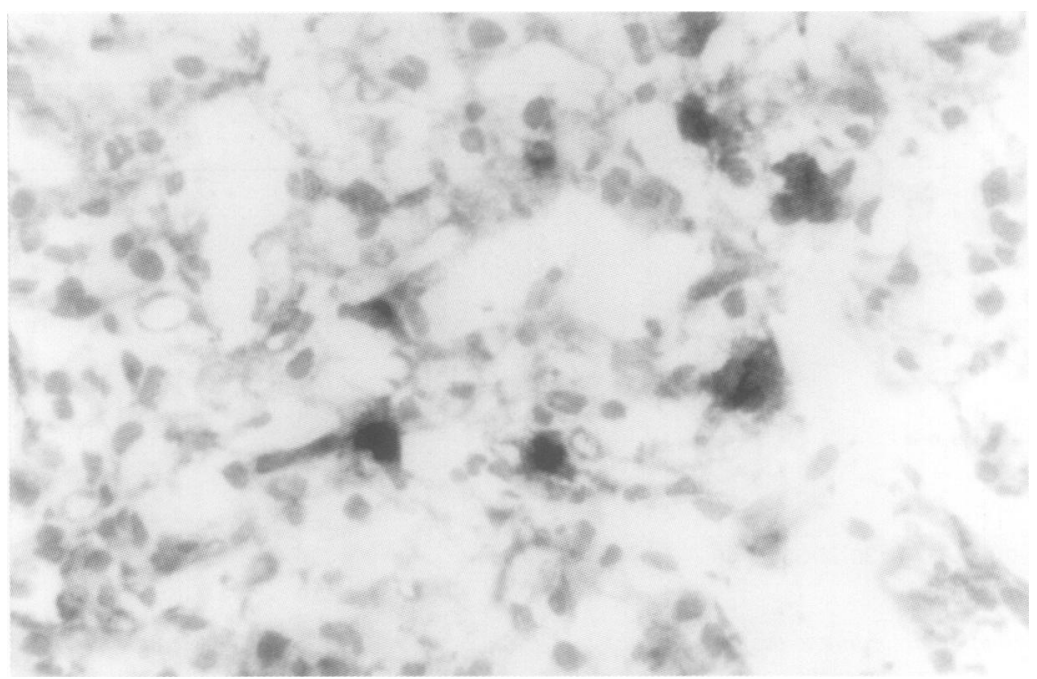

Figure 3 Immunostaining with an anti-IL-6R monoclonal antibody in the same renal cell carcinoma case as shown in fig 2: six positive cells are seen around a blood vessel

(Haematoxylin and eosin, fast red stained; original magnification $\times 250$.)

$$
r=0.34) \text { and stage }(\mathrm{p}=0.0035, r=0.41) \text { but }
$$
not with cytological grade.

\section{SERUM SIL-6R CONCENTRATION}

The mean serum sIL-6R concentration in patients with renal carcinoma was $83.9 \mathrm{ng} / \mathrm{ml}$, (mean 80.5 ; range $38-150$ ). There was no significant difference between these figures and those obtained for controls (mean 95.7; range 39-187). Moreover, there was no correlation with tumour size, nuclear grade, tumour stage, expression of IL-6R or KI-67 in situ, or IL-6 serum and plasma concentrations.

\section{KI-67 IMMUNOSTAINING IN RENAL CELL} CARCINOMA TISSUES

The percentage of positive nuclei was measured in the peripheral zone of the tumour, outside of necrotic zones (fig 2). It ranged between $<1$ and $15 \%$, while the growth fraction only peaked at $1 \%$ in normal renal tissue. Using a $4 \%$ cut off point, we observed a good correlation between KI-67 labelling and tumour stage $(\mathrm{p}=1.54,10-4$, Fisher's exact test), nuclear grade ( $p=8.48,10-3$, Fisher's exact test), and the presence of the the IL-6 receptor in situ ( $p=1.26,10-4$, Fisher's exact test). No correlation between individual growth fractions and tumour size was found.

Table 2 IL-6 receptor immunostaining in renal cell carcinoma tissues

\begin{tabular}{lcll}
\hline & $I L-6 R-v e$ & $I L-6 R+v e$ & Significance \\
\hline Tumour size (cm) & mean 5.9 & mean 7.8 & NS \\
& range $2.2-12$ & range $2.5-13$ & \\
Tumour stage & $7(100 \%)$ & 0 & $\mathrm{p}<0.01$ \\
I & $15(79 \%)$ & $4(21 \%)$ & \\
II & $5(83.3 \%)$ & $1(16.6 \%)$ & \\
III & $1(16.6 \%)$ & $5(83.3 \%)$ & \\
IV & $14(100 \%)$ & 0 & \\
Nuclear grade & $12(70.6 \%)$ & $5(29.4 \%)$ & \\
1 & $2(28.6 \%)$ & $5(71.4 \%)$ & \\
2 & $25(92.6 \%)$ & $2(17.4 \%)$ & \\
3 & $3(27.3 \%)$ & $8(72.7 \%)$ & $\mathrm{p}<0.01$ \\
KI-67 cells & mean 8.32 & mean 48.2 & $\mathrm{p}<0.01$ \\
$<4 \%$ & range $0-100$ & range $0-310$ & \\
$>4 \%$ & mean 87.43 & mean 75.11 & $\mathrm{~N}$ \\
Serum IL-6 (pg/ml) & range $49-150$ & range $38-121$ & \\
Serum soluble IL-6R $(\mathrm{ng} / \mathrm{ml})$ & &
\end{tabular}

Correlation with tumour stage, nuclear grade, percentage of KI-67 positive cells by Fisher's exact test; tumour size, serum IL-6 and serum SIL-6R by Mann-Whitney test.

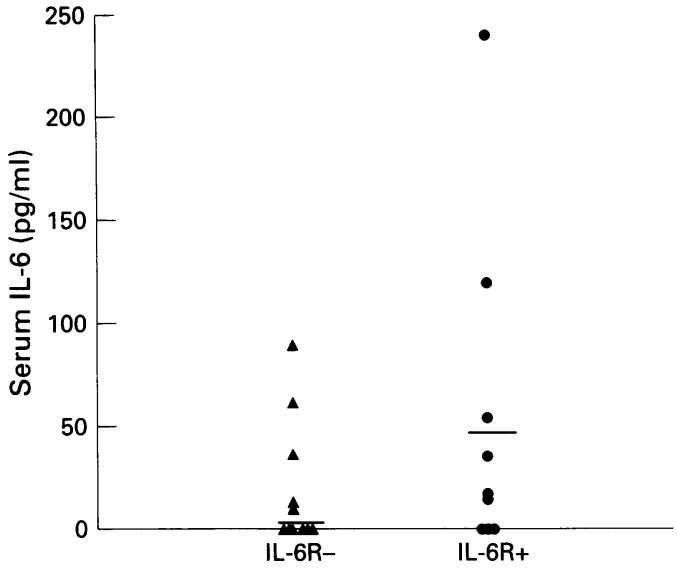

Figure 4 Interleukin-6 serum concentration (pg/ml) in 38 patients with renal cell carcinoma according to IL-6R expression in situ in tumour samples $(p=0.002$, Mann-Whitney test).

IL-6R IMMUNOSTAINING IN RENAL CELL CARCINOMA TISSUES

Ten tumour tissue blocks contained positive cytoplasms (fig 3). Twenty eight were negative. The mean percentage of positive cells in these 10 cases was $4.14 \%$ (range $1.2-9.1 \%$ ). These cells were dispersed randomly in the tumours and did not correlate with KI-67 labelling. Endothelial and inflammatory cells were negative.

Most patients with metastases (stage IV) had some IL-6R positive tumour cells (83.3\%). In contrast, no strictly intrarenal tumours showed positive staining (table 2).

All low histological grade tumours were negative for IL-6R immunostaining and most grade III tumours $(71.4 \%)$ contained some positive cells. Moreover, $92.6 \%$ of renal cell carcinomas with low proliferative rates (KI-67 $<4 \%$ ) remained negative and $72.7 \%$ of tumours with a $>4 \%$ proliferative rate showed positive cells. Interestingly, the serum IL-6 concentration was significantly higher among renal cell carcinoma patients expressing IL-6R compared to those with negative IL-6R tumours (fig 4). Finally, we found a significant correlation between the presence of IL-6R in tumours and tumour stage, nuclear grade, proliferation index, and serum IL-6 concentration $(p<0.01)$. There was no correlation between in situ expression of IL-6R and tumour size or serum sIL-6R concentration. We did not find any correlation between the number of IL-6R positive cells in each case and prognosis.

\section{Discussion}

Many reports have provided evidence of a role for IL- 6 in the proliferation of renal cell carcinoma tumorous cells. IL- 6 is one of the major cytokines involved in inflammatory processes and, thus, it is responsible for a major proportion of the paraneoplastic symptoms seen in patients with renal cell carcinoma. However, the clinical importance of IL-6, sIL$6 \mathrm{R}$, and IL-6R in tumour cells has not yet been established clearly.

In our study, $28.9 \%$ of patients with renal cell carcinoma and $66.7 \%$ of those with metastatic disease had detectable serum IL-6 activity and we noted a good correlation with the 
CRP serum concentration, which reflects the whole production of IL-6 in vivo. As previously demonstrated, CRP is produced by hepatocytes under the control of IL- 6 and the CRP serum concentration correlates with bioactive circulating IL-6 concentrations. ${ }^{10}$ Tsukamoto et al reported that $25 \%$ of their 71 patients with renal cell carcinoma had significant serum IL-6 bioactivity. These raised serum concentrations were found in parallel with an increase in the carcinoma grade and progression of the tumour stage. ${ }^{14}$ In our study, there was a good correlation between IL- 6 concentration, histological grade, proliferation index, and tumour stage. The clinical impact was demonstrated by the difference in overall survival of patients with or without detectable serum IL-6. Furthermore, Blay et al found that the two linked markers, CRP and IL- 6 serum concentration, were the most powerful prognosis markers present in $48 \%$ of metastatic patients with renal cell carcinoma. In their study, the group of patients with the highest IL-6/CRP serum concentrations showed the worst response to immunotherapy. ${ }^{13}$ Tumour stage, histological grade, and recently, proliferation index were shown to be powerful prognostic factors in independent studies. ${ }^{192627}$ Therefore, serum CRP measurements would seem to be a more practical prognostic index than IL-6 in renal cell carcinoma as demonstrated in different diseases including multiple myeloma and nonHodgin's lymphoma. ${ }^{1028}$ However, these data were only analysed retrospectively and would have to be confirmed in a prospective therapeutic study before being valid for treatment selection.

The exact role of IL-6 in tumour cell growth is not yet clear. It was shown that some renal cell carcinoma tumour cell lines exhibited tumour growth under IL-6 exposure, a situation that was reversed when using anti-IL- 6 in vitro. ${ }^{16}$ However, this response was not observed in all tumour cell lines or in fresh cells. ${ }^{17}$ In vivo, IL-6 accounts for a major part of the paraneoplastic syndrome, including inflammatory signs and hypercalcaemia, as previously demonstrated by our group, ${ }^{29}$ with reversion of these signs when anti-IL-6 monoclonal antibody is used in vivo (unpublished data). Furthermore, in this study some patients had slight objective tumour reduction which correlated with CRP inhibition.

The soluble form of the IL- 6 receptor ( 55 $\mathrm{kDa}$ ), generated through alternative splicing, ${ }^{30}$ has an agonist role: it is able to bind IL-6 and the IL-6/sIL-6R complex can bind and activate the gp130 transducer chain. ${ }^{7}$ We did not note any increased serum sIL-6R concentrations in patients with renal carcinoma compared to controls, although this phenomenom has been observed in multiple myeloma. ${ }^{31}$ Soluble IL-6R (like IL-6) is now considered to be a major growth factor for malignant plasma cells and in large series studies of patients with multiple myeloma both have been shown to be powerful prognostic factors. ${ }^{11} 1231$ However, in our study sIL-6R was not of any prognostic value, possibly because of the relatively low number of patients.
To characterise the role of IL-6 in this disease, it is important to assess the presence of IL-6R on tumour cells. Tanekawa $e t$ al showed that the IL-6 receptor (gp80) was present in $26 \%$ of patients by northern blot analysis and in all samples when using a sensitive polymerase chain reaction technique. ${ }^{18}$ These results suggested the presence of an autocrine process in a subgroup of renal cell carcinoma patients. However, the recent production of monoclonal antibodies specific to IL-6R offers new potential for exploring its role at the protein level in renal cell carcinoma. Different monoclonal antibodies have been developed by several groups including ours. The antibody used in this study recognises different epitopes, including the gp 130 linkage. ${ }^{21}$ Using immunochemistry, we noted IL-6R positive cytoplasm in 10 out of 38 patients $(26 \%)$, but the mean percentage of positive cells was only $4.14 \%$. Possibly, IL-6R expression is detected in so few cells because of a variable expression level and/or because the immunochemical technique used is not a very sensitive method. Non-tumour cells from surrounding tissue (endothelial and inflammatory cells) were negative. Our subgroup of patients expressing IL-6R had the highest aggressive disease with high tumour burden, advanced histological grade, high proliferation rate and CRP/IL-6 serum concentration, as well as the worst prognosis as shown on the survival curve $(60 \%$ survival at two years $v 89 \%$ ). These data allowed us to identify an aggressive subgroup of patients with a clear role of IL- 6 in tumour progression and/or proliferation. New therapeutic approaches could be used to treat such patients including anti-IL-6 strategies, combined anti-IL- 6 therapy and immunotherapy (such as, interferon $\alpha$ and/or IL-2), or new techniques involving disruption of autocrine loops by other anti-IL-6R drugs ${ }^{32}$ that interfere with the binding of gp80 and gp130.

1 Guinan P, Vogelzang N, Frengen A, Chmiel J, Sylvester J, Sener $\mathrm{S}$, et al, and members of the cancer incidence and results committee. Renal cell carcinoma: tumor size, stage and survival. $₹$ Urol 1995;153:901-3.

2 Zbar B, Brauch H, Talmadge C, Linehan M. Loss of alleles of loci on the short arm of chromosome 3 in renal cell carcocion the short arm of chrom

3 Morita R, Saito S, Ishikawa J, Ogawa O, Yoshida O, Yamakawa $\mathrm{K}$, et al. Common regions of deletion on chromosomes $5 \mathrm{q}, 6 \mathrm{q}$, and $10 \mathrm{q}$ in renal cell carcinoma. Cancer Res 1991;51:5817-20.

4 Namus DM, Lynch SA, Rao PH, Anderson S, Jhanwar S, Albino A. Transformation of human kidney proximal tubule cells by a src-containing retrovirus. Oncogene 1991;6:2105-11.

5 Kishimoto T. The biology of interleukin-6. Blood 1989;74: 1-10.

6 Kishimoto T, Akira S, Narazaki M, Taga T. Interleukin-6 family of cytokines and gp130. Blood 1995;86:1243-54

7 Novick D, Engelman H, Wallach D, Rubinstein M. Purification of soluble cytokine receptors from normal human urine by ligand affinity and immunoaffinity chromatograurine by ligand affinity and immun

8 Yasukawa K, Saito T, Fukunaga T, Sekimori Y, Koishihara $\mathrm{Y}$, Fukui $\mathrm{H}$, et al. Purification and characterization of soluble human IL6 receptor expressed in CHO cells. F Biochem 1990;108:673-6.

9 Klein B, Zhang XG, Jourdan M, Content J, Houssiau F, Aarden LA, et al. Paracrine rather than autocrine regulation of myeloma-cell growth and differentiation by interleukin-6. Blood 1989,73:517-23.

10 Bataille R, Boccadoro M, Klein B, Durie B, Pileri A. C-reactive protein and beta-2 microglobulin produce a
simple and powerful myeloma staging system. Blood 1992; 80:733-7.

11 Greipp PR, Gaillard JP, Kalish LA, Oken MM, Miller AM, Kyle RA, et al. Independent prognostic value for serum soluble interleukin-6 receptor (sIL-6R) in Eastern 
cooperative oncology group (ECOG) myeloma trial E9487 [abstract]. Proc Am Soc Clin Oncol 1993;12:404.

12 Kyrtsonis MC, Dedoussis G, Zervas C, Perifanis V, Baxevanis C, Stamatelou M, et al. Soluble interleukin-6 receptor, a new prognostic factor in multiple myeloma. $\mathrm{Br}$ f Haematol 1996;93:398-400.

13 Blay JY, Negrier S, Combaret V, Attali S, Goillot E, Merrouche Y, et al. Serum level of IL-6 as a prognosis factor in me

14 Tsukamoto T, Kumamoto Y, Miyao N, Masumori N, Takahashi A, Yanase $M$. Interleukin-6 in renal cell carcinoma. $\mathcal{f}$

15 Stadler WM, Richards JM, Vogelzang NJ. Serum interleukin- 6 concentrations in metastatic renal cell cancer: correlation with survival but not an independent prognostic indicator [letter]. $\mathcal{F}$ Natl Cancer Inst 1992;84:1835-6.

16 Miki S, Iwano M, Miki Y. Interleukin-6 (IL-6) functions as an in vitro autocrine growth factor in renal cell carcinomas. FEBS Lett 1989;250:607-10.

17 Serve H, Steinhauserg, Oberberg D, Flegel WA, Northoff $H$, Berdel WE. Studies on the interaction between interleukin 6 and human malignant non hematopoietic cell lines. Can6 and human malignant

18 Takenawa J, Kanako Y, Fukyumoto M, Fukatsu A, Hirano T, Fukuyama $H$, et al. Enhanced expression of IL-6 in primary human renal cell carcinoma. $\mathcal{f}$ Natl Cancer Inst 1991; 83:1668-72.

19 Robson C, Churchill B, Anderson W. The results of radical nephrectomy for renal cell carcinoma. $f$ Urol 1960;101: 297-301.

20 Hirata Y, Taga T, Hibi M, Nakano N, Hirano T, Kishimoto T. Characterization of IL6 receptor expression by monoclonal and polyclonal antibodies, $f$ Immunol 1989;143: 2900-6.

21 Liautard J, Gaillard JP, Mani JC, Montero-Julian F, Duperray $\mathrm{C}, \mathrm{Lu} \mathrm{Z}$, et al. Epitope analysis of human interleukin-6 ray C, Lu Z, et al. Epitope analysis of human interleukin-6 Cytokine Netw 1994;5:293-300.
22 Zhang XG, Gaillard JP, Robillard N, Lu ZY, Gu ZJ, Jourdan $\mathrm{M}$, et al. Reproducible obtaining of human myeloma cell ines as a model for tumour stem cell study in human multiple myeloma. Blood 1994;83:3654-64.

23 SAS Institute. SAS/STAT users' guide, version 6.4 th edn, Vol 2. Cary: SAS Institute, 1989:846.

24 Kaplan EL Meier P Non parametric estimation from incomplete observations. $\mathcal{f}$ Am Stat Assoc 1958;53:457-81.

25 Hill C, Com-Nougué C, Kramar A, Moreau T, O'Quigley J, Senoussi R, et al. Analyse statistique des données de survie. Edition INSERM Médecine-sciences Flammarion, Paris, France, 1991

26 Fuhrman S, Lasky L, Limas C. Prognostic significance of morphologic parameters in renal cell carcinoma. Am f Surg Pathol 1982;6:655-63.

27 De Riese W, Crabtree W, Allhoff E, Werner M, Liedke S, Lenis G, et al. Prognostic significance of KI-67 immunostaining in non metastatic renal cell carcinoma. $7 \mathrm{Clin} \mathrm{Oncol}$ 1993;11:1804-8.

28 Seymour J, Talpaz M, Cabanillas F, Wetzler M, Kurzock R. Serum interleukin-6 correlates with prognosis in diffuse large-cell lymphoma. $f$ Clin Oncol 1995;13:575-82.

29 Blay JY, Favrot M, Rossi JF, Wijeness J. Role of interleukin-6 in paraneoplastic thrombocytosis [letter]. Blood 1993;82: 2261-2.

30 Muller-Newen G, Kohne C, Keul R, Hemman U, Muller Esterl W, Wijdenes J, et al. Purification and characterization of the soluble interleukin- 6 receptor from human plasma and identification of an isoform generated through alternative splicing. Eur F Biochem 1996;236:837-42.

31 Gaillard JP, Bataille $R$, Brailly $H$, Zuber $C$, Yasukawa $K$, Attal $M$, et al. Increased and highly stable levels of functional soluble interleukin-6 receptor in sera of pa with monat 820-4.

32 Sporeno E, Savino R, Ciapponi L, Paonessa G, Cabibbo A, Lahm A, et al. Human interleukin-6 receptor superantagonist with high potency and wide spectrum on multiple myeloma cells. Blood 1996;87:4510-19. 